\title{
NEGRO-CAUCASOID DIFFERENCES IN PERMANENT TOOTH EMERGENCE AT A CONSTANT INCOME LEVEL
}

\author{
S. M. Garn, S. T. Sandusky, J. M. Nagy and F. L. Trowbridge \\ Center for Human Growth and Development, The University of Michigan, $1111 \mathrm{E}$. \\ Catherine Street, Ann Arbor, Michigan 48104; and Center for Disease Control, \\ Atlanta, Georgia 30333, U.S.A.
}

\begin{abstract}
Summary--Three-thousand, eight-hundred and sixty-eight low-income American Negro boys and girls showed systematic permanent advancement in tooth emergence compared with 5788 low-income boys and girls of European ancestry. Further matched to within $\$ 160$ per-capita yearly income, the Negro boys and girls evidenced a 0.30 standard deviation emergence advancement of non-uniform or "patterned" nature, with the greatest temporal difference for the mandibular lateral incisors $(0.72-0.73$ S.D.) in both sexes.
\end{abstract}

\section{INTRODUCTION}

AlthOUGH numerous racial differences have been reported for the emergence timing of the permanent teeth (STEGgerda and Hill, 1942; Hurme, 1946; GARN and MOORREES, 1951; GARN, 1952, 1971; TANNER, 1962; HIERNAUX, 1968), apparent racial differences in age at emergence may be viewed with considerable caution (DAHLBERG and MENEGAZ-Bock, 1958). Some are undoubtedly due to differences in the definition of emergence and eruption. Others may be due to sampling effects, which may be as great as $\pm 0.5 \mathrm{yr}$ for the later emerging teeth, and sample size (N) of only 50. Still other differences in timing, of the order of $0.25-0.50 \mathrm{yr}$, may be introduced by differing systems of age-assignment, different class-intervals of age, and methods of compilation and reporting. Finally, nutritional and socio-economic effects must also be considered when comparing middle-class United States children and those in emerging populations at different times.

In the present study, therefore, we have made use of a large sample size $(N \simeq 10,000)$, uniform definitions, a single computer program for calculations using exact ages at the time of examination, a generally lower-income population sample, and further restrictions to a single income-needs grouping. The purpose was to compare emergence timing in American children of European ancestry with American Negro children who possess some 75-80 per cent of African genes (cf. REED, 1969). Attention was given both to overall timing differences, for 14 pairs of permanent teeth $I_{1}-M_{2}$, and differences, tooth by tooth, and tooth class by tooth class, to ascertain possible non-uniform (patterned) effects such as have been suggested in the literature. 


\section{MATERIALS AND METHODS}

The study is based on age-at-tooth-emergence data on 9656 generally lower-income boys and girls, of (1) European ancestry (Caucasoid) and (2) largely-African ancestry, participating in the Ten-State Nutrition Survey of 1968-1970. This number of children, between 4.5 and 16.5 yr of age, encompasses the lowest and highest ages included in the cumulative frequency curves for permanent teeth $\mathbf{I}_{1}-\mathbf{M}_{2}$ (i.e. 1 and 7). It was selected out of a larger total of 15,050 individuals between the first and the twentieth year of life, excluding those of Mexican-American, Puerto Rican, American Indian and Asiatic ancestries.

The data consisted of presence-absence records for each permanent tooth, transferred from optical-scanning precoding forms to magnetic tape after preliminary editing. The data were subjected to further editing, on a State-by-State basis, excluding the states of Texas and Louisiana (for which states birthdates were not available in all cases) but including New York City. Permanent tooth emergence data were derived from the states of California, Kentucky, Massachusetts, Michigan, New York State and New York City, South Carolina, West Virginia and Washington State. The children were selected from geographical and demographic samples with lower income-needs ratios, most of them at, or near, the established "poverty level" of 1.0 in the income-needs ratio (ORSHANSKY, 1965 ), and with very few above an income-needs ratio of $3 \cdot 0$, or approximately $\$ 2340$ per-capita.

For each tooth, the age at emergence $M$ and the standard deviation $(\sigma)$ were computer-calculated using a program that fitted $M$ as the Gaussian mean, and $\sigma$ as with $K$ being the slope $(1 / K \sqrt{ } 2 \pi)$ of the cumulative frequency curve at $M$ (ABRAMOWITZ and STEGUN, 1964; GARN et al., 1972a). Values of $M$ for Negro and Caucasoid children were compared both with respect to the difference in years $(d)$, and separately the differences in $Z$-scores or standard deviation units, using the larger (Caucasoid) population values of $a$ as a reference.

Although the American-Negro and Caucasoid groups were selected from low-income areas, economic comparisons still showed an average difference in income-needs ratio of 0.6 or approximately $\$ 480$ per capita (cf. GARN et al., 1972a). Accordingly, the income-needs and per-capita income differences were further restricted by constructing a subsample of 5210 boys and girls exclusively in the income-needs grouping 0.0-1.49. The mean income-needs ratio for this restricted group was then $\mathbf{0 . 9 3}$ for American Caucasoids and 0.73 for American Negroes, a difference of little more than $\$ 150$ per capita.

\section{RESULTS}

As shown in Table 1, American-Negro boys and girls, of largely African ancestry, tended to be earlier or advanced in age at emergence of all permanent teeth from $\mathrm{I}_{1}$ to $\mathrm{M}_{2}$, without exception. This is true both for the maxillary teeth and for the mandibular teeth, for boys and for girls. Actual race differences ranged from little more than $0.07 \mathrm{yr}$, for the lower canine in girls, to as much as $0.55 \mathrm{yr}$ for the lower lateral incisor in girls. Overall, a total of 3868 Negro boys and girls were dentally advanced over 5788 boys and girls of European ancestry by some 0.26 standard deviation units or $Z$-scores. Specifically, the mean difference in emergence timing is 0.25 S.D. for boys, and 0.27 S.D. for girls, and these differences are highly significant. Whether the total number of 214,359 individual sides is considered, or the average number of sides for all 14 teeth, or the average number of children represented for any single tooth, the emergence differences between the groups are significant at far better than the 0.001 level of confidence. In detail, values of $t$ average $56.6,15 \cdot 1$ and $10 \cdot 7$, respectively, for race differences for each sex depending upon the type of comparison.

From Table 1, it is evident that certain teeth and certain tooth groups exhibited the greatest race difference in emergence. There was the most difference for the incisors (mean $Z 0.45$ ), and then the molars (mean $Z 0.26$ ), and the least racial difference for the premolars (mean $Z 0 \cdot 14$ ) and for the canines (mean $Z 0 \cdot 14$ ). Overall, there was 
TABLE 1. THE RACIAL DIFFERENCE IN TOOTH EMERGENCE

\begin{tabular}{|c|c|c|c|c|c|c|c|c|c|c|c|c|}
\hline \multirow[b]{3}{*}{ Tooth } & \multicolumn{4}{|c|}{ Boys } & \multirow[b]{3}{*}{$d^{*}$} & \multirow[b]{3}{*}{$Z$} & \multicolumn{4}{|c|}{ Girls } & \multirow[b]{3}{*}{$d^{*}$} & \multirow[b]{3}{*}{$\boldsymbol{Z}$} \\
\hline & \multicolumn{2}{|c|}{ Caucasoid } & \multicolumn{2}{|c|}{ Negro } & & & \multicolumn{2}{|c|}{ Caucasoid } & \multicolumn{2}{|c|}{ Negro } & & \\
\hline & No. & Mean & No. & Mean & & & No. & Mean & No. & Mean & & \\
\hline \multicolumn{13}{|c|}{ Maxilla } \\
\hline $\begin{array}{l}\text { I1 } \\
\text { I2 } \\
\text { C } \\
\text { P1 } \\
\text { P2 } \\
\text { M1 } \\
\text { M2 }\end{array}$ & $\begin{array}{l}4434 \\
4354 \\
6166 \\
4938 \\
5358 \\
3905 \\
6149\end{array}$ & $\begin{array}{r}7.34 \\
8 \cdot 39 \\
11 \cdot 29 \\
10.64 \\
11 \cdot 21 \\
6 \cdot 40 \\
12.44\end{array}$ & $\begin{array}{l}3284 \\
3598 \\
3949 \\
3897 \\
4063 \\
3070 \\
3423\end{array}$ & $\begin{array}{r}6.93 \\
7.95 \\
10.93 \\
10.45 \\
11.09 \\
6.30 \\
12.30\end{array}$ & $\begin{array}{l}0.41 \\
0.44 \\
0.36 \\
0.19 \\
0.12 \\
0.10 \\
0.14\end{array}$ & $\begin{array}{l}0.53 \\
0.44 \\
0.26 \\
0.13 \\
0.08 \\
0.13 \\
0.10\end{array}$ & $\begin{array}{l}3932 \\
4007 \\
5024 \\
3775 \\
4818 \\
2515 \\
4057\end{array}$ & $\begin{array}{r}6.98 \\
7.97 \\
10.62 \\
10.17 \\
10.88 \\
6.35 \\
11.95\end{array}$ & $\begin{array}{l}3104 \\
2763 \\
2884 \\
3409 \\
\mathbf{3 3 3 9} \\
\mathbf{3 4 6 2} \\
\mathbf{3 2 1 0}\end{array}$ & $\begin{array}{r}6.74 \\
7.67 \\
10.54 \\
10.00 \\
10.71 \\
6.00 \\
11.63\end{array}$ & $\begin{array}{l}0.24 \\
0.30 \\
0.08 \\
0.17 \\
0.17 \\
0.35 \\
0.32\end{array}$ & $\begin{array}{l}0.32 \\
0.33 \\
0.06 \\
0.12 \\
0.11 \\
0.47 \\
0.26\end{array}$ \\
\hline \multicolumn{13}{|c|}{ Mandible } \\
\hline $\begin{array}{l}\text { I1 } \\
\text { I2 } \\
\text { C } \\
\text { P1 } \\
\text { P2 } \\
\text { M1 } \\
\text { M2 }\end{array}$ & $\begin{array}{l}4434 \\
4303 \\
4983 \\
4755 \\
4305 \\
2825 \\
3920\end{array}$ & $\begin{array}{r}6.30 \\
7.47 \\
10 \cdot 52 \\
10 \cdot 70 \\
11.43 \\
6 \cdot 33 \\
12.00\end{array}$ & $\begin{array}{l}2647 \\
2778 \\
4043 \\
4098 \\
4293 \\
3118 \\
3073\end{array}$ & $\begin{array}{r}6.07 \\
6.97 \\
10.34 \\
10.47 \\
11.10 \\
6.11 \\
11.90\end{array}$ & $\begin{array}{l}0-23 \\
0.50 \\
0.18 \\
0.23 \\
0.33 \\
0.22 \\
0.10\end{array}$ & $\begin{array}{l}0.28 \\
0.64 \\
0.16 \\
0.17 \\
0.20 \\
0.28 \\
0.07\end{array}$ & $\begin{array}{l}2630 \\
3510 \\
4626 \\
3955 \\
5425 \\
2484 \\
3880\end{array}$ & $\begin{array}{r}6.18 \\
7.13 \\
9 \cdot 78 \\
10 \cdot 17 \\
10.97 \\
6.15 \\
11.49\end{array}$ & $\begin{array}{l}3072 \\
3036 \\
3214 \\
2528 \\
4027 \\
3592 \\
3918\end{array}$ & $\begin{array}{r}5 \cdot 89 \\
6 \cdot 58 \\
9 \cdot 71 \\
10 \cdot 00 \\
10 \cdot 74 \\
5.73 \\
11.20\end{array}$ & $\begin{array}{l}0.29 \\
0.55 \\
0.07 \\
0.17 \\
0.23 \\
0.42 \\
0.29\end{array}$ & $\begin{array}{l}0.37 \\
0.67 \\
0.06 \\
0.13 \\
0.15 \\
0.55 \\
0.24\end{array}$ \\
\hline Mean & & & & & & 0.25 & & & & & & 0.27 \\
\hline
\end{tabular}

* $d$ is the difference in hundredths of a year, $Z$ is the difference expressed as standard seores relative to the standard deviations for Caucasoids, No, refers to the number of sides (cf. GARN et al., 1973).

consistency between the two sexes in the amounts of relative racial difference in permanent tooth emergence and, with the sample sizes indicated above, the tendency for greater racial differences in molar and incisor emergence is highly significant.

If we attempt to explain these patterned (class-specific) differences in the degree of racial differentiation with respect to location or position in the arch, no systematic relationship emerges using the rank-order correlation. To be more specific, ranking position (mesial to distal) and magnitude of the difference $(0 \cdot 3,0.2$, etc.), the value of $\rho$ is not significant either for boys or for girls. However, if the magnitude of the toothspecific racial difference in emergence liming is related to the age at appearance $(M)$, there are significant associations whether the median order for American Caucasoids or the median order for American Negroes is used. For boys, the race-associated

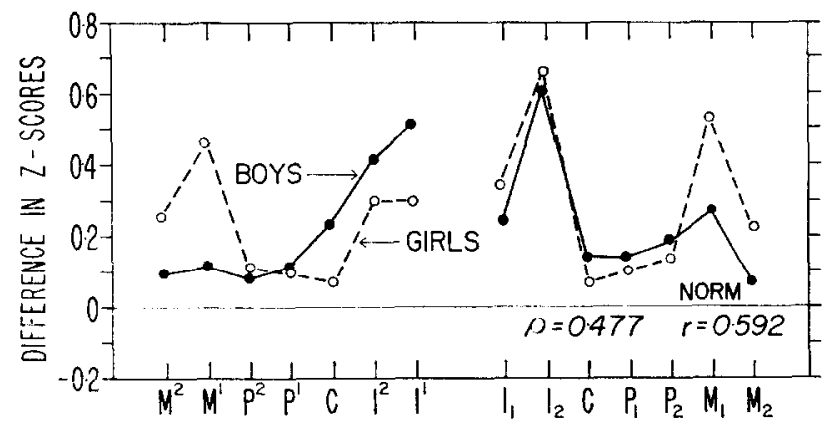

Fig. 1. The strongly-patterned nature of Negro-Caucasoid differences in tooth emergence as shown by similar $Z$-scored difference patterns between Negro and Caucasoid boys (solid lines) and Negro and Caucasoid girls (dashed lines). Data as in Table 1. 
differences in emergence show negative values of $\rho$ of from 0.596 to 0.626 , roughly -0.61 as a compromise. For girls, the rank-order correlation between the racial difference (expressed as $Z$ ) and the median age at appearance of the corresponding tooth $(M)$ is -0.612 using Caucasoid median ages and -0.634 using Negro median ages. It follows, then, that the relative magnitudes of the Negro-Caucasoid differences in age at emergence are systematically and inversely related to the median age at emergence for the teeth in question.

While the data in Table 1 indicate the magnitude of Negro-Caucasoid difference in postnatal permanent tooth timing, and show that the Negro children are systematically ahead by some $0 \cdot 26 \mathrm{Z}$-scores, these data do not show the extent to which the racial difference may be attenuated by economic effects. Even for the generally lowincome group under study, the children of European ancestry tend to have higher income-needs ratios than the Negro children (cf. The Ten-State Nutrition Survey Report of 1972), and we have previously shown that there is a small, but appreciable economic impact on permanent tooth eruption (GARN et al., 1972b).

TABle 2. RACE DifFerence in EMERgenCe timing AT CONSTANT INCOME

\begin{tabular}{|c|c|c|c|c|c|c|c|c|c|c|c|c|}
\hline \multirow[b]{3}{*}{ Tooth } & \multicolumn{4}{|c|}{ Boys } & \multirow[b]{3}{*}{$d^{*}$} & \multirow[b]{3}{*}{$\mathcal{Z}$} & \multicolumn{4}{|c|}{ Girls } & \multirow[b]{3}{*}{$d^{*}$} & \multirow[b]{3}{*}{$z$} \\
\hline & \multicolumn{2}{|c|}{ Caucasoid } & \multicolumn{2}{|c|}{ Negro } & & & \multicolumn{2}{|c|}{ Caucasoid } & \multicolumn{2}{|c|}{ Negro } & & \\
\hline & No. & Mean & No. & Mean & & & No. & Mean & No. & Mean & & \\
\hline \multicolumn{13}{|c|}{ Maxilla } \\
\hline $\begin{array}{l}\text { I1 } \\
\text { I2 } \\
\text { C } \\
\text { P1 } \\
\text { P2 } \\
\text { M1 } \\
\text { M2 }\end{array}$ & $\begin{array}{l}1654 \\
1660 \\
1756 \\
1830 \\
1560 \\
1439 \\
1500\end{array}$ & $\begin{array}{r}7.40 \\
8.51 \\
11.45 \\
10.63 \\
11.17 \\
6.47 \\
12.45\end{array}$ & $\begin{array}{l}2508 \\
2740 \\
3004 \\
2970 \\
3044 \\
2359 \\
2352\end{array}$ & $\begin{array}{r}6.96 \\
7.97 \\
10.97 \\
10.45 \\
11.22 \\
6.25 \\
12.32\end{array}$ & $\begin{array}{r}0.44 \\
0.54 \\
0.48 \\
0.18 \\
-0.05 \\
0.22 \\
0.13\end{array}$ & $\begin{array}{r}0.57 \\
0.53 \\
0.35 \\
0.13 \\
-0.03 \\
0.28 \\
0.10\end{array}$ & $\begin{array}{l}1294 \\
1520 \\
1453 \\
1479 \\
1640 \\
1090 \\
1357\end{array}$ & $\begin{array}{r}7.02 \\
7.95 \\
10.78 \\
10.18 \\
10.87 \\
6.35 \\
12.01\end{array}$ & $\begin{array}{l}2356 \\
2080 \\
2167 \\
2388 \\
1969 \\
2211 \\
2431\end{array}$ & $\begin{array}{r}6.75 \\
7.64 \\
10.66 \\
10.06 \\
10.73 \\
5.95 \\
11.61\end{array}$ & $\begin{array}{l}0.27 \\
0.31 \\
0.12 \\
0.12 \\
0.14 \\
0.40 \\
0.40\end{array}$ & $\begin{array}{l}0.36 \\
0.34 \\
0.09 \\
0.09 \\
0.09 \\
0.54 \\
0.33\end{array}$ \\
\hline \multicolumn{13}{|c|}{ Mandible } \\
\hline $\begin{array}{l}\text { I1 } \\
\text { I2 } \\
\text { C } \\
\text { P1 } \\
\text { P2 } \\
\text { M1 } \\
\text { M2 }\end{array}$ & $\begin{array}{l}1566 \\
1566 \\
1798 \\
1317 \\
1480 \\
1013 \\
1151\end{array}$ & $\begin{array}{r}6.37 \\
7.54 \\
10.61 \\
10.79 \\
11.47 \\
6.36 \\
12.05\end{array}$ & $\begin{array}{l}1739 \\
2131 \\
3082 \\
3119 \\
3277 \\
2221 \\
2339\end{array}$ & $\begin{array}{r}6.11 \\
6.98 \\
10.38 \\
10.40 \\
11.18 \\
6.10 \\
11.96\end{array}$ & $\begin{array}{l}0.26 \\
0.56 \\
0.23 \\
0.39 \\
0.29 \\
0.26 \\
0.09\end{array}$ & $\begin{array}{l}0.32 \\
0.72 \\
0.20 \\
0.28 \\
0.18 \\
0.33 \\
0.07\end{array}$ & $\begin{array}{r}1477 \\
1435 \\
1532 \\
1622 \\
1339 \\
844 \\
1308\end{array}$ & $\begin{array}{r}6.29 \\
7.15 \\
9.84 \\
10.15 \\
10.96 \\
6.15 \\
11.50\end{array}$ & $\begin{array}{l}2052 \\
1790 \\
2328 \\
1716 \\
2814 \\
2050 \\
2875\end{array}$ & $\begin{array}{r}5.87 \\
6.55 \\
9.81 \\
10.09 \\
10.75 \\
5.67 \\
11.21\end{array}$ & $\begin{array}{l}0.42 \\
0.60 \\
0.03 \\
0.06 \\
0.21 \\
0.48 \\
0.29\end{array}$ & $\begin{array}{l}0.53 \\
0.73 \\
0.02 \\
0.05 \\
0.14 \\
0.63 \\
0.24\end{array}$ \\
\hline Mean & & & & & & 0.29 & & & & & & 0.30 \\
\hline
\end{tabular}

* $d$ is the difference in decimal fractions of a year, $Z$ is the difference expressed in standard deviation ( $Z$-score) units. All comparisons are made for the same income-needs ratio grouping, with a mean per-capita income of $\$ 569$ and $\$ 725$, respectively.

Accordingly, the analysis given in Table 1 was extended to a special subsample of 5210 boys and girls (3022 Negroes and 2188 Caucasoids) within the income-needs category $0 \cdot 0-1 \cdot 49$. The boys and girls in this sub-sample came very close to the poverty level, on the average, and there was little difference in per-capita income between the two racial groups. With the smaller sub-sample of 5210 boys and girls as shown in Table 2, the race-associated differences in permanent tooth emergence timing are then similar to those reported in Table 1, but slightly larger. Overall, Negro boys are then $0.29 \mathrm{Z}$-scores advanced over their Caucasoid counterparts and Negro girls 0.30 S.D. ahead in permanent tooth emergence. Thus, for comparable 
income-needs ratios, $0 \cdot 00-1 \cdot 49$, and a comparable per-capita income of close to $\$ 600$, Americans of Negro ancestry then proved to be 0.3 S.D. advanced over those of European ancestry in the emergence of the 7 permanent teeth in each of the 4 quadrants.

\section{DISCUSSION}

The data in this study clearly show advanced emergence for all permanent teeth of American Negro boys and girls, by amounts up to $0.55 \mathrm{yr}$ for particular teeth, and averaging 0.26 standard deviation units both for boys and for girls. Correcting also for the Orshansky income-needs ratio, and/or per-capita income, the averaged degree of American Negro dental advancement rises slightly, to 0.30 standard deviation units or $Z$-scores for 14 pairs of permanent teeth, $I_{1}-M_{2}$. In view of the large sample sizes, the generally low-income groupings to start with, and further correction to virtually identical per-capita incomes, the racial differences summarized here would appear to describe emergence differences between American Negro boys and girls, largely of West African ancestry, and American boys and girls, to the greater extent derived from Northern and Western Europe, Ireland and Britain.

While the emergence differences of $0 \cdot 26-0.30 Z$-scores describe the average differences for the 14 pairs of teeth considered, racial differences in permanent tooth emergence are obviously non-uniform or patterned, within the dentition, and to a rather similar extent between the two sexes. As has been suggested by previous workers (cf. HIERNAUX, 1968), the racial difference is greatest for the mandibular lateral incisor ( $\mathrm{I}_{2}$ or $\overline{2}$ in different notations), and least for the teeth of the canine area $\left(C\right.$ and $\left.P_{1}\right)$. There is a relationship between the relative magnitude of $Z$-score differences in Negro-Caucasoid emergence timing, and the age at emergence of the permanent teeth, such that the earlier emerging teeth show somewhat greater relative $(Z$-score) differences. Evidently, the racial differences in permanent tooth emergence are regularly patterned, and the developing dentition does not behave as a single unit, in terms of evolutionary differences, any more than it behaves as a single functional unit.

Besides answering the primary question, the magnitudes of Negro-Caucasoid differences in permanent tooth emergence timing, both for the entire dentition and the component teeth, these findings have evident bearing on the forensic applications of tooth emergence data, and further applications to prehistoric and fossil remains. Since emergence data are clearly population-specific, errors of approximately $0.5 \mathrm{yr}$ could occur in making age-estimates of juvenile cadavers or skeletal remains. Such crrors would be proportionately greater for such teeth as the lower lateral incisors, and proportionately less for the canines and second permanent premolars ( $\mathrm{P} 3$ in the evolutionary sequence).

Finally, it is clear that for permanent tooth emergence, as for ossification timing and other measures of skeletal status, racial differences (here those between AmericanNegro and American-Caucasoid children) exceed developmental differences due to economic factors and their nutritional concomitants. Indeed, lower-income AmericanNegro boys and girls, are dentally advanced over higher-income European boys and 
girls approximating the U.S.A. median. Only in comparing clinically malnourished American-Negro boys and girls with the economically more-favoured and developmentally-advanced American children of European ancestry, might we expect a reversal of the racial differences confirmed here, and suggested by the earliest studies of STEGgerda and HiLl (1942). Otherwise, population differences in tooth emergence here and previously given exceed socio-economic differences in emergence by a factor of two or more.

Acknowledgements-Data collection and data analysis was supported by Contract HSM 21-72-522 with the Center for Disease Control, Atlanta, Georgia and additional computer work was completed under Grant DE 03443-01 with the National Institute for Dental Research, NIH, Bethesda, Md. We thank RichaRD L. MiLler for the development of the computer program, Tecla Caryl Loup for assistance in the completion of the data analysis and ShirLeY M. GarReTt for completion of the manuscript and tables.

Note: During the course of the 10-State Survey participants were self-identified as "Black", "White", Mexican-American, etc. following standard U.S. Census categories. The terms Negro and Caucasoid are used here for editorial uniformity.

\begin{abstract}
Résumé-3868 garçons et filles Noirs Américains à bas revenu, ont montré un permanent avancement systématique de l'apparition des dents comparés avec 5788 garçons et filles à bas revenu, d'origine Européenne. Ultérieurement comparés avec un groupe avant un revenu per capita, jusqu'à $\$ 160$ par an, les garçons et les filles Noirs montrèrent une déviation standard de 0,30 dans l'avancement de l'apparition, d'une nature nonuniforme ou "modelée", avec la plus grande différence temporelle pour les incisives mandibulaires latérales $(0,72-0,73$ S.D.) dans les deux sexes.
\end{abstract}

Zusammenfassung-Dreitausendachthundertundachtundsechzig amerikanische Negerjungen und Mädels aus niedriger Einkommenklasse wiesen systematisches, ständiges Vorrücken von Zahnemergenz im Vergleich zu 5788 Jungen und Mädchen aus niedrigen Einkommenklassen europäischen Ursprungs auf. Weiterhin wiesen die Negerjungen und Mädchen, innerhalb von 160 Dollar pro Kopf jährlichen Einkommens passend zusammengestellt, ein Emergenzvorrücken von 0,30 Standardabweichung ungleichförmiger oder "Muster" Art auf, mit dem grössten zeitweiligen Unterschied in den seitlichen Unterkieferschneidezähnen (0,72-0,73 S.D.) bei beiden Geschlechten.

\title{
REFERENCES
}

Abramowitz, M. and Stegun, I. A. 1964. Handbook of Mathematical Functions. AMS 55, U.S. Government Printing Office, Washington.

Dahlberg, A. A. and Menegaz-Bock, R. M. 1958. Emergence of the permanent teeth in Pima Indian children. J. dent. Res. 37, 1123-1140.

Garn, S. M. 1952. Physical growth and development. Am. J. Phys. Anthrop. 10, 169-192.

GARN, S. M. 1971. Human Races, 3rd edn. Thomas, Springfield, Ill.

Garn, S. M. and Moorrees, C. F. A. 1951. Stature, body build and tooth emergence in the Aleutian Aleut children. Child Develop. 22, 262-270.

Garn, S. M., SANDUSKy, S. T., NAGY, J. M. and McCanN, M. B. 1972a. Advanced skeletal development in low-income Negro children. J. Pediat. 80, 965-969.

Garn, S. M., SANDusky, S. T., Rosen, N. N. and Trowbridge, F. 1973b. Economic impact on postnatal ossification. Am. J. Phys. Anthrop. 37, 1-4.

Garn, S. M., Wertheimer, F., Sandusky, S. T. and McCann, M. B. 1972b. Advanced tooth emergence in Negro individuals. J. dent. Res. 51, 1509. 
HieRnAuX, J. 1968. Ethnic differences in growth and development. Eugen. Quart. 15, 12-21.

HuRME, V. O. 1946. Decay of the deciduous teeth of Formosa Chinese. An analytical summary and interpretation of certain statistics published by Maruyama. J. dent. Res. 25, 127-136.

OrShansky, M. 1965. Counting the poor: Another look at the poverty profile. Soc. Sec. Bull. 28, 3-29.

ReED, T. E. 1969. Caucasian genes in American Negroes. Science 165, 762-768.

StegGerdA, M. and Hill, T. J. 1942. Eruption time of teeth among Whites, Negroes, and Indians. Am. J. Orthodont. Oral Surg. 28, 361-370.

TANNER, J. M. 1962. Growth at Adolescence, 2nd edn. Blackwell, Oxford.

Ten-State Nutrition Survey 1968-1970. 1972. No. (HSM) 72-8134, U.S. Dept. of Health, Education, and Welfare, Center for Disease Control, Atlanta, Ga. 